\title{
Public Transport Mode Model Selection for public Transport Users in the City of Makassar Based on the Change of Speed Travel Variables
}

\author{
Syahlendra ${ }^{1, a}$ \\ ${ }^{1}$ Civil Engineering Department, State Polytechnic of Ujung Pandang, Jalan Perintis Kemerdekaan Km 10 Tamalanrea \\ Makassar, 90245, Indonesia \\ ${ }^{\mathrm{a}}$ syahlendrassyahrul@poliupg.ac.id
}

\begin{abstract}
The increasing number of private vehicles shows that the public transportation system in Makassar has not been maximized. this is also due to the absence of other alternative public transportation modes that can be used by the community in their activities. This study aims to determine the preference of public modes of choice if offered other alternatives, especially public transport with greater capacity. Public transportation offered in this study is busway and monorail. In this study the community was faced with 3 modes of choice namely city transportation, monorail, and busway. The data collection method used was a survey with stated preference based questionnaires, which reviewed nine conditions for variable change in travel speed. The construction of the model was carried out using STATA software and city transportation was used as the base outcome. The model is based on discrete selection models and is analyzed by the multinomial logit model. The results showed that in the nine conditions of change in travel speed, the mode of city transportation was still more dominantly chosen by the community.
\end{abstract}

Keywords: public transportation, multinomial logit model, STATA

\section{Introduction}

Urban Public Transportation (called Pete-pete) can be said to be the only mass public transportation service in the city which is still operating normally in City of Makassar. Problems then arise because little by little the people begin to move from the mode of urban public transportation to the private vehicles mode in carrying out their activities. This is indicated by the number of private vehicle ownership are increasing from year to year. Based on data from the central statistical agency [1], the number of private vehicle ownership in Makassar City in 2015, for passenger cars was 190.428 and for motorcycles as much as 1.062.943. Based on Makassar City Samsat data, the number of vehicles in 2016 reached 1,128,809 units. From 2017 to October
2018 the vehicle reaches $1,563,608$ units. with vehicle growth rates in the city of Makassar among at $14 \%$ $15 \%$ per year [2].

Urban Public transportation (Pete-pete) Operation is also actually felt to be less effective and does not reduce transportation problems in Makassar City. This is because in addition to the small transport capacity, poor driver behavior is also sometimes the cause of congestion itself. The city transportation (pete-pete) in Makassar City is approximately 4113 fleets, divided into 17 routes and has a seating capacity of 11 passengers, with details of 6 passengers on the inside, 4 on the outside and 1 beside the driver [3].

One solution that can be done to overcome transportation problems in the city of Makassar is to maximize the planning of a good mass public transportation system, especially public transportation with a large transport capacity. This is very important to do immediately, especially with the continued development of online small-capacity public transport which also greatly contributes to increasing the volume of traffic on the road. By maximizing the planning of mass public transport with large capacities, it is hoped that the community will move from small capacity transport modes to greater capacity public transportation modes, so that can reduce the volume of vehicles on the road.

Syahlendra and M. Isran Ramli [4] conducted research on mode selection between urban public transportation, busway and monorail based on changes in travel cost variables. The result of the research shows that in all conditions of change of travel cost variable, 
public of city transportation user still prefer to use city transportation than using busway or monorail mode.

This study reviewed how the probability of the community, especially people who use urban public transportation (pete-pete) in choosing public transportation if given other alternative public transportation in carrying out their activities. The public transport offered is public transport that has a large transport capacity, namely mass public transportation types of busway and monorail.

\section{Research Methodology}

\section{A. Variables and Data Research}

\section{Research Variables}

The dependent variable reviewed in this study is the probability of the choice of public transportation modes of Urban public transportation (pete-pete), busway or monorail. The independent variables reviewed are taken from 3 categories, namely individual character, trip characteristics, and the level of transportation services. The individual character categories reviewed are the education, occupation and income of the respondent, the character category of the trip reviewed is the amount of ride (moving) of city transportation and for the category of transportation service level, the variable reviewed is the speed travel variable.

In processing data with a multinomial logit model, the qualitative independent variables must first be broken down into several groups, so that in inputting with the multinomial logit model format with STATA, these qualitative independent variables can be quantified by writing the number 1 for the appropriate variable and the number 0 for non-matching variables. Table 1 shows the independent variables used.

Table 1. Independent Variable Used

\begin{tabular}{|c|c|c|}
\hline No. & Independent Variables & Symbol \\
\hline 1 & $\begin{array}{c}\text { last education 1 (Middle school and } \\
\text { below) }\end{array}$ & $\mathrm{x} 1$ \\
\hline 2 & last education 2 (College) & $\mathrm{x} 2$ \\
\hline 3 & last education 3 (postgraduate) & $\mathrm{x} 3$ \\
\hline 4 & Income & $\mathrm{x} 4$ \\
\hline 5 & $\begin{array}{c}\text { Joob 1 (PNS/BUMN, TNI/POLRI, } \\
\text { Teacher/Lecture, Private employees) }\end{array}$ & $\mathrm{x} 5$ \\
\hline 6 & Joob 2 (Student) & $\mathrm{x} 6$ \\
\hline 7 & Joob 3 (Entrepreneur and others) & $\mathrm{x} 7$ \\
\hline 8 & $\begin{array}{c}\text { The amount of transportation users } \\
\text { moved (1 time) }\end{array}$ & $\mathrm{x} 8$ \\
\hline 9 & The amount of transportation users & $\mathrm{x} 9$ \\
\hline
\end{tabular}

\begin{tabular}{|l|c|c|}
\hline & moved (2 time) & \\
\hline 10 & Speed Travel & $\mathrm{xK}$ \\
\hline
\end{tabular}

\section{Research Data}

Data in this study were obtained using a questionnaire that was designed based on stated preferences. The stated preference method has been a popular method for measuring multi-attribute products or services [5]. Design of the questionnaire shows respondent the needs for additional modes that must be accessed if using the busway or monorail mode. That needs for additional mode has resulted in changes in travel speed to access busway or monorail mode.

Additional modes for accessing busway stops or monorail stations reviewed in this study are the taxi bike and the urban public transportation (pete-pete) mode itself. In this study, respondents were offered 9 conditions of variations in changes the travel speed variables due to variations in changes in the type of additional modes that must be accessed to go to and leave the busway stop or monorail station. Table 2 . shows the questionnaire design that shows 9 conditions of variations in the variable speed of travel due to variations in the addition of modes to access busway stops or monorail stations.

Table 2. Stated Preferences Questionnaire Based on Changes in Travel Speed Variables

\begin{tabular}{|c|c|c|c|c|c|c|c|c|c|c|}
\hline \multirow{3}{*}{$\begin{array}{c}\text { No } \\
1\end{array}$} & \multirow{2}{*}{$\begin{array}{l}\text { Pilihan } \\
\text { Moda }\end{array}$} & \multirow{2}{*}{\begin{tabular}{|c|} 
A \\
Pete2
\end{tabular}} & \multicolumn{4}{|c|}{ B } & \multicolumn{4}{|c|}{ C } \\
\hline & & & taxibike- & Busway & - taxibike & Average & taxibike & -Monorail- & taxibike & Average \\
\hline & speed (mm hours) & 16 & 35 & 34 & 35 & 34.7 & 35 & 47.5 & 35 & 39.2 \\
\hline \multirow{2}{*}{2} & Moda & Pete2 & taxibike- & Busway & - taxibike & Average & Pete2 & -Monorail- & Pete2 & Average \\
\hline & speed (m hours) & 16 & 35 & 34 & 35 & 34.7 & 16 & 47.5 & 16 & 26.5 \\
\hline \multirow{2}{*}{3} & Moda & Pete2 & taxibike- & Busway & - taxibike & Average & taxibike & -Monorail- & Pete2 & Average \\
\hline & speed (m/ hours) & 16 & 35 & 34 & 35 & 34.7 & 35 & 47.5 & 16 & 32.8 \\
\hline \multirow{2}{*}{4} & Moda & Pete2 & Pete2 - & Busway & - Pete2 & Average & taxibike & -Monorail- & taxibike & Average \\
\hline & speed (m hours) & 16 & 16 & 34 & 16 & 22.0 & 35 & 47.5 & 35 & 39.2 \\
\hline \multirow{2}{*}{5} & Moda & Pete2 & Pete2 - & Busway & - Pete2 & Average & Pete2 & -Monorail- & Pete2 & Average \\
\hline & speed (m hours) & 16 & 16 & 34 & 16 & 22.0 & 16 & 47.5 & 16 & 26.5 \\
\hline \multirow{2}{*}{6} & Moda & Pete2 & Pete2 - & Busway & - Pete2 & Average & taxibike & -Monorail- & Pete2 & Average \\
\hline & speed (Am hours) & 16 & 16 & 34 & 16 & 22.0 & 35 & 47.5 & 16 & 32.8 \\
\hline \multirow{2}{*}{7} & Moda & Pete2 & taxibike- & Busway & - Pete2 & Average & taxibike & -Monorail- & taxibike & Average \\
\hline & speed (m hours) & 16 & 35 & 34 & 16 & 28.3 & 35 & 47.5 & 35 & 39.2 \\
\hline \multirow{2}{*}{8} & Moda & Pete2 & taxibike- & Busway & - Pete2 & Average & Pete2 & -Monorail- & Pete2 & Average \\
\hline & speed (m/m hours) & 16 & 35 & 34 & 16 & 28.3 & 16 & 47.5 & 16 & 26.5 \\
\hline \multirow{2}{*}{9} & Moda & Pete2 & taxibike- & Busway & - Pete2 & Average & taxibike & -Monorail- & Pete2 & Average \\
\hline & speed (m/ hours) & 16 & 35 & 34 & 16 & 28.3 & 35 & 47.5 & 16 & 32.8 \\
\hline
\end{tabular}

The population in this study is the users of urban public transportation (pete-pete) in Makassar City, this population is approached as an infinite or unclear population because it is uncertain and changes every day. Based on the calculation of the number of samples for infinite or unclear populations, it is known that the number of samples taken was as many as 1570 respondents divided into 16 routes with a percentage ratio of the number of samples per route, according to 
the percentage of the number of urban public transport (pete-pete) fleets per route.

The survey was conducted in the Makassar City area, which is carried out on urban public transportation (petepete) on 16 routes that were reviewed. The survey is carried out for 2 weeks or until the total target number of samples has been reached.

\section{B. Data Processing and Analysis}

Data processing was done by using a multinomial logit model using STATA program by making the Urban Public transportation mode (pete-pete) as the base outcome. Multinomial logit models are used to model relationships between a polytomous response variable and a set of regressor variables [6]. the multinomial logit (MNL) model is a popular model for the stated preference method, although it relies on the assumption that its attributes have no correlations [5]. The analysis results of the data obtained are the Utility model of public transportation mode selection for busway mode and the monorail mode, and the probability of community selection for each public transportation mode being reviewed.

\section{Utility Model of the Mode Selection}

The results of processing with the STATA program in which the public transportation mode (pete-pete) is used as the base outcome, then produces the coefficient of the utility model selection mode for busway mode and monorail mode for each variation of the variable conditions reviewed.

The coefficient obtained is then built into the busway mode selection utility model and the monorail mode selection utility model for each variation of the variable conditions reviewed. The general form of the modal choice utility model is shown by the linear regression equation [7]:

$$
\mathrm{Y}=\mathrm{C}+\beta \mathrm{x} 1+\beta \mathrm{x} 2+\ldots+\beta \mathrm{nxn}
$$

\section{Utility value of the mode selection}

After the mode selection utility model for busway mode and monorail mode is obtained, then the average value of each independent variable (x) that has been calculated is entered into the model that has been built. By entering the average value of the independent variable $(\mathrm{X})$ that is used in the mode selection utility model that has been built, then the utility value is obtained from the busway mode and monorail mode for each variation of variable conditions under review.

\section{Probability value of each mode selection}

After obtaining the utility value of public transport mode selection for the busway and monorail mode for each variation of the variable conditions reviewed, then the utility value is entered into the multinomial logit model formula to find the probability value of each mode selection for each variation of the condition and variable being reviewed. general modal choice probability equations with multinomial logit models [8]:

$$
P(i)=\frac{e^{y U i}}{e^{y U i+\sum_{e} y U j n}}
$$

Where:

$\mathrm{P}(\mathrm{i})$ = Probability of mode selection $\mathrm{i}$

eyUi $=$ Utility Exponential of mode selection $\mathrm{i}$

eyUjn $=$ Utility Exponential of mode selection $\mathrm{j}$ to mode $\mathrm{n}$

With the urban public transportation (pete-pete) mode as the base outcome, ey (Upete-pete) $=1$. Then the multinomial logit model equation to find the probability of each mode is:

$$
\begin{gathered}
P(\text { Upete - pete })=\frac{1}{1+_{e} y(U b)+_{e} y(U m)} \\
\mathrm{P}(\text { Busway })=\frac{e y(U b)}{1+_{e} y(U b)+_{e} y(U m)} \\
P(\text { Monorail })=\frac{e_{e} y(U m)}{1+_{e} y(U b)+_{e} y(U m)}
\end{gathered}
$$

So by using the three probability equations above, the probability value of each mode can be determined.

\section{Results and Discussion}

\section{A. Utility model of mode selection}

After the terms and significance of the model are reviewed, then the coefficients of each independent 
variable coming out of the results of processing with the STATA program are built into a mode selection utility model. Table 3. Shows the utility model obtained.

Table 3. Utility model of mode selection

\begin{tabular}{|c|c|c|}
\hline Cond & Mode & Model obtained \\
\hline \multirow[b]{2}{*}{1} & busway & $\begin{array}{c}\mathrm{Y}=-1,4340 \times 1-1,4631 \times 2-0,0568 \times 4+0,0043 \times 6- \\
0,0388 \times 7+2,5213 \times 8+2,6688 \times 9-0,1187 \times \mathrm{K}\end{array}$ \\
\hline & monorail & $\begin{array}{c}\mathrm{Y}=1,0500 \times 1+1,5665 \times 2+0,0560 \times 4+0,2689 \times 6- \\
0,1374 \times 7-0,3036 \times 8-0,1187 \times K\end{array}$ \\
\hline \multirow{2}{*}{2} & busway & $\begin{array}{c}\mathrm{Y}=-1,4467 \times 1-1,4033 \times 2-0,0736 \times 4-0,1262 \times 6+ \\
0,0936 \times 7-0,2422 \times 8+0,0430 \times K\end{array}$ \\
\hline & monorail & $\begin{array}{c}=-3,8078+1,7749 \times 1+2,0493 \times 2+0,1467 \times 4+ \\
0,1758 \times 5+0,6273 \times 6-0,2296 \times 8+0,0430 \times K\end{array}$ \\
\hline \multirow{2}{*}{3} & busway & $\begin{array}{c}Y=0,0692 \times 1+0,0144 \times 2-0,0924 \times 4-0,1576 \times 6- \\
0,1311 \times 7-0,1630 \times 8-0,0315 \times K\end{array}$ \\
\hline & monorail & $\begin{array}{c}\mathrm{Y}=0,1586 \times 1+0,3529 \times 2+0,1308 \times 4+0,3753 \times 6- \\
0,1495 \times 7-1,2116 \times 8-0,9934 \times 9-0,0315 \times \mathrm{K}\end{array}$ \\
\hline \multirow{2}{*}{4} & busway & $\begin{array}{c}\mathrm{Y}=-0,9866 \times 1-0,8039 \times 2-0,1331 \times 4+0,1485 \times 5- \\
0,1759 \times 6+0,8399 \times 8+1,0173 \times 9-0,1091 \times \mathrm{K}\end{array}$ \\
\hline & monorail & $\begin{array}{c}\mathrm{Y}=0,8036 \times 1+0,8984 \times 2+0,1434 \times 4+0,3462 \times 6- \\
0,3209 \times 7-0,1960 \times 8-0,1091 \times K\end{array}$ \\
\hline \multirow{2}{*}{5} & busway & $\begin{array}{c}\mathrm{Y}=-0,6881 \times 1-0,5828 \times 2-0,1397 \times 4+0,0372 \times 5- \\
0,3814 \times 6+2,0642 \times 8+2,2610 \times 9-0,3197 \times \mathrm{K}\end{array}$ \\
\hline & monorail & $\begin{array}{c}\mathrm{Y}=1,8551 \times 1+2,0687 \times 2+0,1641 \times 4+0,5154 \times 6- \\
0,0276 \times 7-0,1834 \times 8-0,3197 \times \mathrm{K}\end{array}$ \\
\hline \multirow{2}{*}{6} & busway & $\begin{array}{c}\mathrm{Y}=-0,3700 \times 1-0,4601 \times 2-0,0731 \times 4+0,7336 \times 5+ \\
0,3999 \times 6+0,5704 \times 7-0,1588 \times 8-0,1264 \times \mathrm{K}\end{array}$ \\
\hline & monorail & $\begin{array}{c}Y=0,4416 \times 1+0,7161 \times 2+0,1522 \times 4+0,5052 \times 6- \\
0,0264 \times 7-0,0922 \times 8-0,1264 \times K\end{array}$ \\
\hline \multirow{2}{*}{7} & busway & $\begin{array}{c}Y=-0,0730 \times 1-0,0927 \times 2-0,1129 \times 4-0,0262 \times 5- \\
0,2921 \times 6-0,4832 \times 8-0,3966 \times 9-0,0222 \times K\end{array}$ \\
\hline & monorail & $\begin{array}{c}\mathrm{Y}=-1,0563 \times 1-0,7198 \times 2+0,0660 \times 4+0,3379 \times 6- \\
0,0341 \times 7-0,4415 \times 8-0,0222 \times K\end{array}$ \\
\hline \multirow{2}{*}{8} & busway & $\begin{array}{c}Y=-0,3827 \times 1-0,5098 \times 2-0,0414 \times 4-0,0477 \times 6+ \\
0,1593 \times 7-0,1171 \times 8-0,0250 \times K\end{array}$ \\
\hline & monorail & $\begin{array}{c}\mathrm{Y}=0,7335 \times 1+1,1921 \times 2+0,1153 \times 4-2,1078 \times 5- \\
1,6052 \times 6-2,0380 \times 7-0,1231 \times 8-0,0250 \times \mathrm{K}\end{array}$ \\
\hline \multirow{2}{*}{9} & busway & $\begin{array}{c}\mathrm{Y}=-0,8944 \times 1-1,1201 \times 2-0,0813 \times 4+1,5395 \times 5+ \\
1,3270 \times 6+1,5207 \times 7-0,0855 \times 8-0,1139 \times \mathrm{K}\end{array}$ \\
\hline & monorail & $\begin{array}{c}Y=0,1707 \times 1+0,7295 \times 2+0,1235 \times 4+0,6047 \times 6+ \\
0,0278 \times 7-0,2308 \times 8-0,1139 \times K\end{array}$ \\
\hline
\end{tabular}

Table 3. shows 9 mode selection utility models for the busway and monorail based on the 9 changes in the reviewed travel speed variables

\section{B. Utility value of the mode selection}

After processing the data with the STATA program, we obtain 9 utility modes were selected for the busway and monorail modes for variable travel speeds. Then by entering the average value of each independent variable that has been calculated previously into the modal choice utility model equation that has been built, then the value of the mode selection utility can be obtained.
Table 4. shows the utility and exponential utility values of the busway and monorail mass public transportation modes for the 9 variable conditions of travel speed, where the public transport modes (pete-pete) are the base outcome for processing with a multinomial logit model.

Table 4. Busway and monorail utility values for 9 conditions of variable travel speed

\begin{tabular}{|c|c|c|c|}
\hline Condition & Mode & Utility mode & EXP Utility mode \\
\hline \multirow{2}{*}{1} & Busway & $-1,9517$ & 0,1420 \\
\cline { 2 - 4 } & Monorail & $-1,8467$ & 0,1578 \\
\hline \multirow{2}{*}{2} & Busway & $-0,7936$ & 0,4522 \\
\cline { 2 - 4 } & Monorail & $-0,5631$ & 0,5694 \\
\hline \multirow{2}{*}{3} & Busway & $-1,1270$ & 0,3240 \\
\cline { 2 - 4 } & Monorail & $-1,3801$ & 0,2516 \\
\hline \multirow{2}{*}{4} & Busway & $-2,7161$ & 0,0661 \\
\cline { 2 - 4 } & Monorail & $-1,3895$ & 0,2492 \\
\hline \multirow{2}{*}{5} & Busway & $-5,3847$ & 0,0046 \\
\cline { 2 - 4 } & Monorail & $-4,1588$ & 0,0156 \\
\hline \multirow{2}{*}{6} & Busway & $-2,8045$ & 0,0605 \\
\cline { 2 - 4 } & Monorail & $-1,7709$ & 0,1702 \\
\hline \multirow{2}{*}{7} & Busway & $-1,4094$ & 0,2443 \\
\cline { 2 - 4 } & Monorail & $-1,5861$ & 0,2047 \\
\hline \multirow{2}{*}{8} & Busway & $-1,1197$ & 0,3264 \\
\cline { 2 - 4 } & Monorail & $-1,4588$ & 0,2325 \\
\hline \multirow{2}{*}{9} & Busway & $-2,3187$ & 0,0984 \\
\cline { 2 - 4 } & Monorail & $-1,9703$ & 0,1394 \\
\hline
\end{tabular}

\section{Probability value of each mode selection}

Figure 1 shows the probability value of each mode selection for the 9 conditions of the variable travel speed changes, where each condition shown the different average of travel speed caused there is a need to use other modes to access busway stops and monorail station.

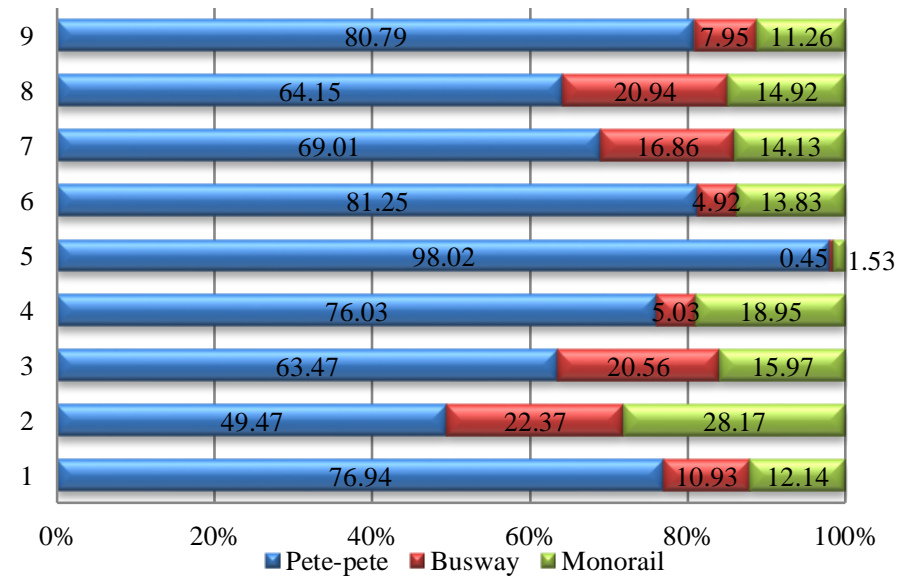

Figure 1. Probability selection of travel speed variable

Figure 1 shows the probability of choosing the pete-pete, busway and monorail mode based on 9 variations in the 
change in the travel speed variable. It is known that the greatest probability value for the pete-pete mode is in condition 5 with a value of $98.02 \%$, where in this condition it is shown that the average speed of the busway and monorail modes is at the lowest average speed. for the busway mode, the greatest probability is in the second condition with a probability value of $22.37 \%$ selection. In this condition, the average travel speed for the busway mode is shown in the fastest condition. for the monorail mode, the greatest probability is also in the second condition with a probability value of selection of $28.17 \%$. where in this condition the average travel speed for the monorail mode is actually at the lowest speed, so it is analyzed that there are other factors that affect the probability value of selecting the monorail mode in that condition.

\section{Conclusion}

The probability of mode selection in 9 conditions reviewed shows that urban public transportation (petepete) is still preferred by urban public transport (petepete) users compared to busway or monorail. Based on the analysis conducted, the results were obtained because that nine condition reviewed was shown the needs for additional modes to access busway or monorail mode.

\section{Acknowledgement}

Our gratitude goes to Mr. Isran Ramli and Mr. Nur Ali who have guided and supported us in carrying out this research. Our gratitude also goes to the leadership and staff of The State polytechnic Ujung Pandang, especially the civil engineering department staff.

\section{References}

[1] Central Statistical Agency, "Jenis Kendaraan 2015," (Vehicle Type 2015), Badan Pusat Statistik Sulawesi Selatan, 03 Juli 2015. [Online].Available:

https://sulsel.bps.go.id/indicator/17/703/1/jenis-kendaraan.html. [Accessed 21 Januari 2021].

[2] Rijal, "Koordinasi Dinas Perhubungan dan Satuan Lalu Lintas dalam Penanggulangan Kemacetan Kota Makassar," (Coordination of the Transportation Service and Traffic Units in Makassar City Congestion Management), MATRA PEMBARUAN, vol. 3, no. 1, pp. 47-56, 2019.

[3] Makassar Transportation and Communications Office, The routes and fleets number of urban public transportation (pete-pete) of Makassar city in 2013, Makassar: dinas perhubungan dan komunikasi kota Makassar, 2013.

[4] Syahlendra and M. I. Ramli, "Studi Pemilihan Moda Angkutan Umum untuk Pengguna Angkutan Kota di Kota Makassar Berdasarkan Perubahan Biaya Perjalanan," (Study on the Selection of Public Transport Mode for Urban Transport Users in Makassar City Based on Changes in Travel Costs) in Simposium Forum Studi Transportasi antar Perguruan Tinggi ke-20, Makassar, 2017.

[5] F. M. Tseng and Y. J. Chiu, "Hierarchical fuzzy integral stated preference method for Taiwan's broadband service market," Omega, vol. 33, no. 1, pp. 55-64, 2005.

[6] Y. So and W. F. Kuhfeld, "Multinomial logit models," in SUGI 20 conference proceedings, Cary, NC, 1995.

[7] M. Z. Irawan, "Modeling Travel Mode Choice: Application Of Discrete- Continuous Model," in Simposium FSTPT 14, Pekanbaru, 2011.

[8] R. W. Simanjuntak and M. S. Surbakti, "Analisa Pemilihan Moda Transportasi Medan-Rantau Prapat dengan Menggunakan Metode Stated Preference," (Analysis of the choice of the Medan-Rantau Prapat mode of transportation using the Stated Preference Method), Jurnal Teknik Sipil USU, vol. 2, no. 1, 2013. 